\title{
EMPATHY FOR SOCIAL JUSTICE: THE CASE OF MALALA YOUSAFZAI
}

\author{
Ana Belén Martínez García \\ Universidad de Navarra \\ abmartinezg@unav.es
}

\begin{abstract}
This essay demonstrates the effectiveness of human rights life narratives in garnering global support through their appeal to empathy. I focus on Nobel Peace Prize winner Malala Yousafzai's autobiographical texts and their impact on lives outside the written pages, which is first and foremost of an empathic nature. The essay pays special attention to her childhood blog and her teenage autobiography, looking at the narrative strategies employed in both. Autobiographical texts are never neutral, enabling people to see themselves under a new light, spurring them to act. The delicate balance between witnessing and involvement hangs on the creation of an emotional bond.
\end{abstract}

Keywords: Malala Yousafzai, empathy, human rights, autobiography, blog, narrative. 


\title{
EMPATÍA Y JUSTICIA SOCIAL: EL CASO DE MALALA YOUSAFZAI
}

\begin{abstract}
RESUMEN. Este artículo demuestra la eficacia de las narrativas autobiográficas acerca de derechos humanos en conseguir atención y apoyo global gracias a su llamada a la empatía. Me centro en los textos autobiográficos de la Premio Nobel de la Paz Malala Yousafzai y en su impacto en vidas dentro y fuera de sus páginas, de naturaleza primordialmente empática. El artículo atiende especialmente al blog que escribió de niña y a su autobiografía de juventud, buscando dar luces sobre las estrategias narrativas empleadas en ambos. Los textos autobiográficos nunca son neutrales, lo cual permite al lector verse desde otro punto de vista y moverse a la acción. El equilibrio entre dar testimonio y participar depende en gran medida de la capacidad del texto de promover un vínculo emocional.
\end{abstract}

Palabras clave: Malala Yousafzai, empatía, derechos humanos, autobiografía, blog, narrativa.

Received 13 February 2018

Revised version accepted 24 April 2019

\section{INTRODUCTION}

In this essay, I explore Malala Yousafzai's autobiography, I Am Malala: The Girl Who Stood Up for Education and Was Shot by the Taliban (Yousafzai and Lamb 2013), as well as other instances of Malala's life narrative project to show how she deploys empathy to garner support for her cause - education for girls. Born in Pakistan in 1997, Malala has become a public figure, known only by her first name, primarily because of the Taliban's shooting of her in an attempt to silence her activism. She has led a public life from girlhood, beginning with a blog for the BBC when she was eleven ("Diary" 2009). Then, she appeared in two New York Times documentaries between the ages of eleven and twelve, but it was the terrorist attack that made her a global icon. That happened when she was fifteen, and, since then, she has become an advocate for the cause of girls' education worldwide, going on to speak at the United Nations and to win the Nobel Peace Prize for her advocacy and message of forgiveness.

Drawing from Kay Schaffer and Sidonie Smith's seminal work Human Rights and Narrated Lives, I use the term "life narrative" "as an umbrella term that encompasses the extensive array and diverse modes of personal storytelling that takes experiential history as its starting point [...] oral or written testimony" (2004: 7). This blend of oral and written text for testimonial purposes is precisely what defines Malala Yousafzai's life narrative as she uses storytelling to narrate her life but also as a vehicle to denounce rights transgressions on a broader scale. Schaffer and Smith claim that "life narratives have become one of the most potent 
vehicles for advancing human rights claims" (2004: 1). Further, they note the efficacy of these life narratives in the context of human rights abuse, emphasizing the role these stories may play in society while at the same time acknowledging their dangers:

\begin{abstract}
Stories may generate strong sensations, feelings, and embodied responses for tellers and their audiences, at times of first and subsequent witnessing. [...] Sensations [...] can promote healing and solidarity among disaffected groups and provide avenues for empathy across circuits of difference. They can activate interest [...]. They can also [...] turn subjects of story into spectacle, reduce difference to sameness, and induce exhaustion. While affect offers a potential for change, for becoming, it is impossible to predict how sensations will be channeled into knowledge or practice. (2004: 6-7)
\end{abstract}

The difficulty inherent to human rights life narratives is also discussed in We Shall Bear Witness: Life Narratives and Human Rights, edited by Meg Jensen and Margaretta Jolly (2014). However, despite qualms as to truth claims or the "commodification of narratives of suffering" (Smith and Watson 2010: 17), life narratives have the potential to become "potent weapons in political movements" (219). Indeed, Jolly refers to the need to look "at the mobilization of public concern through personal accounts and life story narrations as a frequently neglected dimension of change and delivery" (2014: 4). Anthropologist Marianne Gullestad notes that life narratives can "have a potentially transformative impact on 'society'" (1996: 32), as those that describe human rights abuse, such as Malala's, can influence decisions that are made on a global scale. Malala's autobiographical exercises, constructed through multiple channels, may have led her to the Nobel Peace Prize and might lead to future legislation. An intrinsic part of her identity as an education activist, her campaign for global access to equal quality education is ongoing.

Empathy is arguably one of the most salient characteristics of life narratives, particularly those associated with human rights causes. Schaffer and Smith have discussed how activists deploy rights discourse to "capture the interest, empathy, and political responsiveness of readers" (2004: 27). Sidonie Smith and Julia Watson explain, drawing on Schaffer and Smith's theory, that "scenes of witness entwine the narrator, the story, and the listener/reader in an ethical call for empathic identification and accountability, recognition, and oftentimes action" (2010: 133134). The sort of reaction these highly affective texts will elicit will depend on the socio-political context of reception, on the personal circumstances of the reader, and multiple other reasons. However, these life narrative projects would inevitably be bound for oblivion or disregard without empathy as a narrative tool. Indeed, the testimonial nature of the witnessing act embedded in human rights life narratives 
requires the reader to engage with the text in a way conducive to "empathic identification" (Whitlock 2015: 9). Otherwise, without the reader as witness, the testimonial text fails - "the sound of one hand clapping" (68). For rights claims to be recognized, therefore, activists turned life narrators need to ensure their texts succeed in affecting the reader emotionally before they can effect change.

Philosopher Martha C. Nussbaum defines "empathy" as the ability "to see the world from another's viewpoint" (2012: 36), which bears a close relationship to theories of reader reception: "We integrate what we have read into our reading of other texts and into our way of looking at ourselves and the world" (Schwarz 2001: 15). Cognitivists have pointed to a link between literature and "pro-social behavior" (Hammond and Kim 2014: 7-8). The idea that empathy is related to "prosocial" behavior had earlier been proposed by social psychologists such as Nancy Eisenberg (1982). The "empathy-altruism hypothesis" posed by Daniel C. Batson (1991) has played a vital role, but it has also been subject to criticism. Thus, Amy Shuman argues that an empathic stance may create voyeurs out of readers; in that sense, there might be empathy but no real change: "Empathy offers the possibility of understanding across space and time, but it rarely changes the circumstances of those who suffer. If it provides inspiration, it is [...] for those in the privileged position of empathizer rather than empathized" (2005: 5). However, Richard Rorty (1993), among others, deems life narratives of suffering as more important than reason in constructing new ideas of rights thanks to empathic identification (qtd. in Jolly 2014: 7). Perhaps the key to seeing empathy in relation to altruism lies in a redefinition of altruism acknowledging that the other is already part of us:

\footnotetext{
We talk about political actions as some kind of obligation that we owe, as individuals, to society, to others: we should be altruistic, not "self-centered". But if we are characters, social creatures by origin and definition, political and philanthropic actions are not performed out of duty to others but as acts of "self"-preservation; if the others are in me, "altruism" - the service of alterity - and selfishness must either not be contrasted at all, or if they are contrasted the lines must be drawn in new ways. (Booth 1988: 243-244)
}

Cultivating our emotions may therefore have a positive impact on "our reasoning capacity as political creatures" (Nussbaum 2001: 3), even if the danger of falling into self-indulgence needs to be acknowledged (399). Needless to say, empathy is not the panacea to all of humanity's problems. Shuman points out that there has been major criticism against the risk of over-empathizing: "Appropriation can use one person's tragedy to serve as another's inspiration and preserve, rather than subvert, oppressive situations" (2005: 5). The answer may lie in distinguishing empathy from identification, as LaCapra suggests: "empathy may be contrasted 
with identification (as fusion with the other) insofar as empathy marks the point at which the other is indeed recognized and respected as other, and one does not feel compelled or authorized to speak in the other's voice or take the other's place, for example, as surrogate victim or perpetrator" (2001: 27). Though I agree with the concerns regarding an overly optimistic vision of empathy, I believe that it has the potential for social good, as it provides insight into other people's lives. Through the lens of empathy, life narratives that deal with human rights abuse lead the public to understand why injustice is unacceptable and consider their role in making changes.

Suzanne Keen's theory of narrative empathy may shed light on activist autobiographical texts. Keen sees authorial "strategic narrative empathy" as "representational techniques aimed at moving their readers [...] especially the case of nonfiction narratives that link up with the advancement in human rights" (2016: 20). Among the three types of authorial narrative empathy discussed by Keen, Malala's texts combine two: "ambassadorial strategic empathy" (20) and "broadcast strategic empathy" (22). Malala's life narrative project deploys "ambassadorial strategic empathy" to bring to light a current cause - the Taliban attacks on girls' education. But, as Keen cautions, such time-sensitive causes have sell-by dates (20). On the other hand, "broadcast strategic empathy" employs "universals that will reach everyone" thus overcoming the durability criteria of "less robust strategic empathizing" (22). Keen concludes that texts may blend "empathetic appeals" to secure durability (22). With this in mind, I argue that Malala deploys both ambassadorial and broadcast empathy to a point where her message will persist the passing of time. As Keen defines it, "strategic empathizing works by calling upon familiarity; it attempts to transcend differences in order to deflect biased reactions to characters from outgroups. It can also rely on representations of universal human experiences to connect through shared feelings" (20). I will focus on precisely how Malala enacts this, as I explore the "narrative devices" that draw the reader in by calling on "common human experiences, feelings, hopes, and vulnerabilities" (22), namely the choice of pronouns, emphatic repetition, rhetorical questions, humor, and the appeal to common human experiences and feelings that binds them all. Indeed, these practices are all intertwined, and progressively combined in her later texts. In what follows, I focus on Malala Yousafzai's autobiographical texts to illustrate what human rights life narratives can do. Specifically, I signal the way Malala's autobiographical texts deploy empathy as a call to action. In order to do that, she uses what Martínez García calls "empathetic mechanisms" (2016), resorting to universal topics that promote the articulation of an emotional bond in such a way as to "move people in two distinct ways - emotionally and to action" (127). These mechanisms are designed 
to lead people to share her feelings and want to help her in her fight for global education. Thus, she appeals to our shared experience of childhood, adolescence, human emotions and the multiple channels through which she may connect with an international readership and mobilize empathy.

\section{MALALA, THE CHILD BLOGGER ${ }^{1}$}

When she was just 11, the BBC Urdu branch in Pakistan contacted Swati schools because they wanted an inside view on what Talibanization was doing to girls' and women's daily lives. The BBC was interested in a blog, a first-person testimonial on the part of a Swati teacher or a schoolgirl. With growing Taliban presence in the region of Swat valley, and the surge of violence against women in what were considered to be Western attitudes such as clothing, walking somewhere on their own without a male escort, or receiving education other than religious, the situation that women and girls were living was not getting enough attention. Public flogging, for example, had become a common spectacle in the area. For obvious reasons, the BBC insider would be protected by using a pseudonym - Gul Makai.

Malala was not the BBC's first choice. However, there was an element of Malala's personal life that proved decisive: her father. Whereas other girls that were contacted had no qualms whatsoever and were even excited at the prospect of writing for the BBC, their parents were set against it, considering the risk their daughters would be placing themselves in. What set Malala apart from other girls was, ultimately, the fact that her father was fearless. Ziauddin Yousafzai had been vocal about the right of all children to education in the region of Swat since before Malala was born. His fluent Pashto, Urdu and English, even if at times impaired by nerves, made him a prominent figure (Yousafzai and Lamb 2013: 115). Her father's fellow activists were acquainted with her and accustomed to having her sit in their meetings. As she remembers, they would say "Malala is not just the daughter of Ziauddin [...] she is the daughter of all of us" (116). Ziauddin encouraged all the pupils at his school to speak out against the ban on girls' education (117). Malala's step into the limelight was thus the natural response of a committed daughter to one of her father's greatest ideals - girls' education.

The diary had quite a short life, but proved to be very successful. It received so many visits that it was later translated into English ("Diary" 2009) and posted

\footnotetext{
1 Douglas and Poletti have discussed Malala's blog in Life Narratives and Youth Culture: Representation, Agency and Participation (2016: 203-224). They provide an in-depth analysis of the blog as an example of how youth activism online may influence education policies. Douglas has further analyzed what she calls Malala's "collaborative archive" (2017), paying special attention to the collaborative nature of her life narrative project. However, this essay takes a different stance, as it focuses on strategic empathy as the key to explain how Malala's youth-authored autobiographical texts succeed in garnering support.
} 
on the mainstream BBC website. In the first entry, entitled "SATURDAY 3 JANUARY: I AM AFRAID”, Gul Makai talks about the Taliban edict banning girls from going to school: "On my way from school to home I heard a man saying 'I will kill you'. I hastened my pace and after a while I looked back [sic] if the man was still coming behind me. But to my utter relief he was talking on his mobile and must have been threatening someone else over the phone" ("Diary" 2009). Malala's fears were grounded in reality, as later events proved. Crucially, though the blog is personal, her concerns are shared by many other girls in her country and in many other places all over the world where girls are not allowed to go to school. The choice of the pronoun "I" to stand for a collectivity is a narrative device, the first instance of her authorial strategic empathizing (Keen 2016: 20). The testimonial form of the "I" exemplifies Keen's concept of "ambassadorial strategic empathy" (20), focusing on the group at a disadvantage, here the community of girls from the Global South whose education is at stake. Gul Makai's blog was designed as an "exemplary narrative [...] strategically deployed to personalize the story [...] [and] lend specificity to the suffering attached to this particular rights violation" (Schaffer and Smith 2004: 175). In Malala's case, the right that comes under threat is the right to education. Thus, Gul Makai's first entry makes the reader wonder to what extent she realized the danger she was in while writing. This "I" speaks for millions of girls worldwide who are out of the educational system for many different reasons, but most particularly those whose surroundings make it impossible for them to attend school, either due to war, health hazards, or socio-cultural constraints. In the same blog entry, a second narrative device designed to generate empathy, the reference to a common human experience - going to school - and the feelings attached to it - ranging from acute awareness to actual fear - is present. Moving from "ambassadorial" to "broadcast" narrative empathy (Keen 2016: 22), the text emphasizes common human experiences to increase its chances of transcending time.

Gul Makai's second entry, "SUNDAY 4 JANUARY: I HAVE TO GO TO SCHOOL", focuses on how dull holidays have become since the arrival of the Taliban in the region and, again, her fear: "Today I did some household chores, my homework and played with my brother. But my heart was beating fast - as I have to go to school tomorrow" ("Diary" 2009). While she used to love school, now she is too afraid to enjoy it. The nuanced repetition of going to school, present in the title, and in block letters to boot, is quite noticeably a further narrative device for strategic empathizing. Girls cannot possibly wish to go to school while under threat. Instead, if forced to do so, they must see it as an obligation outside their control, thus the use of "I HAVE TO GO" instead of must, which would imply a more personal decision. Using Keen's terminology, this extract deploys 
"strategic broadcast empathy" (2016: 20), when it stresses common actions - doing homework, chores, playing - and feelings of many schoolchildren. At the same time, the extract deploys "strategic ambassadorial empathy" (22), as the ominous presence of the Taliban in the region is the reason why she does not want to go to school, not boredom or childhood mischief.

Gul Makai's third entry, "MONDAY 5 JANUARY: DO NOT WEAR COLOURFUL DRESSES", explains how first she is told to avoid a uniform, then told off for choosing a pink dress "as the [sic] Taleban would object to it" ("Diary" 2009). In her fourth entry, "WEDNESDAY 7 JANUARY: NO FIRING OR FEAR”, she uses nostalgia to call on our empathic reactions as she compares her home region of Swat to another geographical region inside Pakistan, Bunair, where there is still peace:

I have come to Bunair to spend Muharram (a Muslim holiday) on vacation. I adore Bunair because of its mountains and lush green fields. My Swat is also very beautiful but there is no peace. But in Bunair there is peace and tranquillity. Neither is there any firing nor any fear. We all are very happy. ("Diary" 2009)

The simple way in which the narrating "I" describes the landscape, marking the contrast between Swat and Bunair, war and peace, fear and happiness, magnifies the empathetic experience for readers, who are compelled to witness through the child's eyes the instability of happiness in warzones. This "child's-eye" perspective in the context of human rights life narratives has been analyzed, among others, by Sidonie Smith (2006). By focusing on the experience of a universal symbol of innocence whose welfare is endangered, the narrating "I" taking up the position of a child stands to gain emotional support through empathic identification. ${ }^{2}$

Gul Makai's fifth entry, "FRIDAY 9 JANUARY: THE MAULANA GOES ON LEAVE?", shows some irony when referring to the Maulana's going on leave, as he was precisely responsible for the ban on girls' education and had been talking on the radio for a while on a regular basis. This entry features another narrative device deployed for strategic empathy - rhetorical, irony-loaded questions, both in the title and in what follows, as she asks poignantly, "why do these blasts keep happening in Pakistan?" ("Diary" 2009). This girl's questions present compelling issues to the reader of the blog; they question our moral understanding of a world that allows situations such as this, where schools are bombed during wartime, to go unnoticed or not given the appropriate attention, for example in the media or by political leaders.

The BBC website chose to leave a blank for entries dated 10-13 January, so there is no way of knowing whether she wrote something those days or not.

\footnotetext{
2 For further analysis of the interplay between the child as a trope and life narrative, see Douglas (2009; 2015); Douglas and Poletti (2016); Smith (2006); Schaffer and Smith (2004).
} 
One might wonder what the fate of the girl in question was, but then silence is followed by relief on reading the following entry, knowing that at least she is alive. What comes next, though, is the expected outcome of the escalation of violence sensed in the previous entries. In "WEDNESDAY 14 JANUARY: I MAY NOT GO TO SCHOOL AGAIN", her school closes down for the holidays and no reopening date is set: "I looked at the building as if I would not come here again" ("Diary" 2009). Just as her 4th-January entry was entitled "I HAVE TO GO TO SCHOOL", ten days later it is "I MAY NOT GO TO SCHOOL AGAIN". This nuanced repetition enhances narrative empathy, and the change of modal verb marks a change of events with serious consequences for daily life. "THURSDAY JANUARY 15: NIGHT FILLED WITH ARTILLERY FIRE" signals the end of the blog, as she almost reveals her true identity. She talks about reading the blog with her parents, and joking about the pseudonym: "My mother liked my pen name 'Gul Makai' and said to my father 'why not change her name to Gul Makai?", ("Diary" 2009). She goes on to say that she likes the name as well, since "my real name means 'grief stricken"” ("Diary" 2009). This interesting use of a combination of irony, humor, and rhetoric, already present in the previous question from the 9th-January entry ("THE MAULANA GOES ON LEAVE?"), is a constant in Malala's narrative, as we shall see later on. By the time this final entry was written, Malala Yousafzai had already appeared in the local news talking about girls' rights to education and had been identified by first and last name. Her identity as the girl behind the blog must have been no longer easy to maintain secret, which could be the reason why she suddenly stopped writing. It might alternatively have been an editorial decision to protect her from harm.

Though short and short-lived, Malala's blog exemplifies all the narrative devices she uses for strategic empathizing purposes, as suggested earlier - the use of personal pronouns, nuanced repetition, rhetorical questions, humor, and appealing to common human experiences and feelings. These devices coexist, at times in the same sentence. In her later autobiographical texts, she will refine their usage until they become embedded in her narrative.

Shortly after the episode that inaugurated Malala's blog, The New York Times shot two documentaries profiling her. Her first appearance before the camera is memorable: "I want to go to school to get my education, and I want to become a doctor" (Ellick and Ashraf 2009). She cannot finish her sentence because she begins to cry. With schools under the threat of being shut down or blown up by the Taliban, her tears reveal her frustration and the apparent impossibility of her dreams. Then, because of Operation True Path, an attempt on the part of the Pakistani military to drive the Taliban out of Swat valley (Yousafzai and Lamb 2013: 146), her family is forced, together with all residents of Mingora, to leave the city and spend months as internally displaced people or "IDPs" (148). When they 
return home and she turns twelve, her father's influence becomes more noticeable. Instead of wanting to become a doctor, now she wants to be a politician and help to change the situation in Pakistan (Ellick 2009). But she has not forgotten her love for books. When she arrives home after months away and sees her schoolwork, she cannot help her tears (Ellick and Ashraf 2009). This emotional outburst triggers an array of complex emotions on the part of the audience: "anger at the perpetrators; empathy with her suffering; critical awareness and activism" (Schaffer and Smith 2004: 150).

In November 2011, Malala tells CNN in an interview: "I have rights. I have the right of education, I have the right to plea, I have the right to sing, I have the right to talk, I have the right to go to market, I have the right to speak up!" (CNN 2013). This insistence on the issue of rights sets the stage for what would become her activist career. Her emphatic repetition is as evident as in any of her other autobiographical texts, more noticeably because of her final shout, something common to all her public speech acts. Her will seems to be one that will not be deterred. Later that year, on 20 December 2011, she is awarded Pakistan's first-ever National Peace Prize (Yousafzai and Lamb 2013: 179). These documents evidence Malala's maturity: her voice has grown stronger, her outspokenness and growing media presence make her more of a target for the Taliban. On 9 October 2012, three armed men stopped her school bus, entered it, and shot her on the left side of her forehead. For Malala, the shooting becomes an emblem, a part of her identity. For the rest of the world, this became an empathetic moment, the reason we came to care. The world could no longer ignore her plight and that of other girls like her, and the issue of women's education again entered the limelight. Malala now became the subject of global news and campaigns flooded the internet.

Having survived the shooting, Malala's advocacy acquired increased urgency. Her story arguably comes across most powerfully in the speech she gave before the United Nations on 12 July 2013, the day of her sixteenth birthday. The effects of the shooting were there - the once-beautiful face of an innocent girl had, in the short space of less than a year, become the gaze of a sage woman. Her discourse contained more determination, intent on provoking listeners, to react, to do something about crimes against girls and women. This was the perfect audience for Malala's message: "world leaders", as she repeatedly insisted (Yousafzai 2013), needed to do more than offer words of consolation: "We call upon the world leaders to change their strategic policies in favor of peace and prosperity. We call upon the world leaders to uphold their peace deals, [sic] must protect women and children's rights" (Yousafzai 2013). Words are used by Malala as weapons in her fight for justice: "We believe in the power and the strength of our words. Our words can change the whole world because we are all together, 
united for the cause of education" (Yousafzai 2013). There is a key shift in the pronouns she deploys, preferring the first person plural rather than the singular, and this marks not only a narrative device for strategic empathizing purposes, but a change in her social status and her awareness of her role as a representative of many other girls (Martínez García forthcoming). Malala's use of the first person plural makes her listeners part of her discourse. We are thus not only recipients of her message, but collaborators. She calls on us to recognize the human rights violations taking place, to empathize and identify with her and her claims and to spur activism (Schaffer and Smith 2004: 192). Thus, Malala creates an emotional bond by appealing to human rights, as well as displaying a universal emotion forgiveness. Instead of seeking retaliation for the violence that she suffered, she maintains that forgiveness "is the legacy of change", an attitude she learned from, among others, Martin Luther King and Nelson Mandela, as well as Gandhi, Mother Teresa, and her parents (Yousafzai 2013). In one sentence, she links iconic symbols of contemporary culture associated with the idea of peace, regardless of religion or skin color. That she chose to reference her diverse role models at the United Nations establishes her socio-political agenda.

Following Malala's UN speech and its impact on the media, she visited Harvard University to receive the Humanitarian of the Year Award, where she argued that the help that countries at war are currently receiving is not what they really need: "instead of sending guns, send pens; instead of sending tanks, send books; instead of sending soldiers, send teachers" (Harvard 2013). This argument connects with her earlier position (Forbes 2014; Yousafzai and Lamb 2013: 131; Westall 2015). Excerpts from Malala's speech at Harvard reveal her strategy of nuanced repetition as she repeats simple short sentences organized in binaries: "instead of [...] send [...]" (Harvard 2013). Indeed, her rhetoric is designed as one typically associated with politicians or activists. Interestingly, at Harvard she chose a discourse that echoes Martin Luther King: "Let us dream today, a dream of a bright future, a world [...] where there is equality and justice, and let us stand up for our rights [...]. Let us make these dreams tomorrow's reality" (Harvard 2013). She also appeared on the Daily Show to present her autobiography. Finally, Malala's increasing popularity allowed her to meet some of the world leaders whose help she needed, including Barack Obama and Queen Elizabeth, whom she presented with her book (ITV 2013).

\section{MALALA, THE TEENAGE AUTOBIOGRAPHER}

Malala's autobiography is her most famous text to date. I now look at the "empathetic mechanisms" (Martínez García 2016) or "narrative devices" (Keen 
2016) that are at work when she writes this text, the particular strategies that she employs to connect to her audience, namely her use of a global discourse that can appeal to wide audiences. The empathetic mechanisms Malala used in her blog and her speeches become much more evident in her autobiography. Specifically, she deploys a sophisticated human rights discourse, insisting on the image of the average teenage girl, referring to God and the idea of the Good; then, her strategic use of fear as a human emotion; and finally, her use of visual testimony to make us participate of her pain, as when she uses photographs or her scribbled notes while in hospital.

The most prominent attempt at transcending difference for strategic empathy is her use of a global discourse (Keen 2016: 20-22). Though some human rights activists focus on the specificities of their culture as key to reading their texts in an appeal to save them while at risk of disappearing, others resort to focusing on what is common to human experience instead. In her text, Malala moves in and out of those two contending discourses, at times presenting what is unique about Pashtun culture, at times revealing what they share with Global North readers. To make a call to empathic identification, these latter remarks are vital. For example, she makes references to popular culture that are not that dissimilar from Global North teenager tastes. She not only mentions literary classics, but also trendy things such as drinking Pepsi (Yousafzai and Lamb 2013: 154), watching Twilight movies (4) and the Ugly Betty series (165), listening to Justin Bieber (4), or reading the Twilight saga: "Moniba and I had been reading the Twilight books and longed to be vampires" (91). As she describes herself in these extracts, Malala seems to capitalize on the notion of the average teenage girl.

Furthermore, in an attempt to overcome ethnic and religious differences that might foreclose global understanding, Malala chooses a unifying discourse that might bridge the gap between readers of other backgrounds. True enough, she engages in a dignifying, apologetic, discourse of her religion. But, instead of referring to "Allah" or "Muhammed", she creates an emotional bond with the reader by making constant references to "God" as the source of her strength, praying to Him and trusting in His eternal Mercy. Choosing the word "God", she makes it easy for a Western audience to empathize. At a time when a self-proclaimed Muslim identity may be controversial, she makes it clear that Muslims are not the enemy: "At night I used to pray a lot. The Taliban think we are not Muslims but we are. [...] I'd pray to God, 'Bless us. First our father and family, then our street, then our whole mohalla, then all Swat'. Then I'd say, 'No, all Muslims'. Then, 'No, not just Muslims; bless all human beings"' (199). Malala's prayer is focused on the reception on the part of the reader, left in wonder at this girl who is capable of enduring suffering and finds the time to pray for the rest of the world. She manages to bind 
readers together in her cause by repeating strategically, as a child would: "then [...] then [...]. No [...] No, not just [...]" (199). In a seemingly simple stroke of narrative genius, readers are all included as potential allies. Morally and emotionally, readers feel compelled, ${ }^{3}$ and much the same could be said of the following extract:

I wrote a letter to God. "Dear God", I wrote, "I know you see everything, but there are so many things that maybe, sometimes, things get missed, particularly now with the bombing in Afghanistan. But I don't think you would be happy if you saw the children on my road living on a rubbish dump. God, give me strength and courage and make me perfect because I want to make this world perfect. Malala". (72)

This extract features the emphatic close repetition of the term "God" (72), which, because it leaves Islamic terms out, makes all readers, independently of religion, part of the discourse. Whereas Malala's prayer is not likely to be answered, it displays a universal emotion - human beings would all like to be the best they can, not only for their own sakes but for the sake of society as a whole. Charles Taylor suggests in Sources of the Self that:

Practical charity is enjoined in us. The Enlightenment took this up in intensified form, and it has become one of the central beliefs of modern Western culture: we all should work to improve the human condition, relieve suffering, overcome poverty, increase prosperity, augment human welfare. We should strive to leave the world a more prosperous place than we found it. (1989: 85)

In appealing to people's charity, to their ingrained sense of responsibility, Malala is making her claims for justice affect all readers. Her text calls for a compassionate response, subject to falling complicit into humanitarian readings whereby readers become "spectators of distant suffering" with all the ethical problems this entails (Whitlock 2015: 110). ${ }^{4}$ And yet, the cause of education for all children remains an unsolved problem in many countries where conditions, unless more initiatives are supported, will not change. The value of life narratives such as Malala's is that, in making rights claims more visible, they achieve recognition and may eventually serve the purpose of influencing public opinion and policymakers.

Fear also marks Malala's narrative. When the Taliban entered the bus, she found herself paralyzed and unable to speak. The exclamation: "I am Malala", caught in her throat, was left unsaid. Now, Malala's narrative is her "survivor narrative" (Alcoff and Gray-Rosendale 1996: 220). Even if silent at that time, now

\footnotetext{
3 I am inspired by Nussbaum's theory of moral emotions as "part and parcel of the system of ethical reasoning" and "guides to ethical choice" (2001: 1). She suggests the interconnectedness of feeling and acting according to our intellectual drive for the benefit of society.

4 See Boltanski (1991), Schaffer and Smith (2004), Chouliaraki (2006) and Hesford (2011), for further criticism on compassionate humanitarian readings of human rights violations.
} 
she is both speaking up and speaking out, raising her voice and raising awareness. Overcoming fear and telling her story, she finds courage: "Who is Malala? I am Malala and this is my story" (Yousafzai and Lamb 2013: 6). That movement from inaction to action makes her all the more relatable. Quite tellingly, she uses both a rhetorical question and a simple repetitive structure to emphasize her transformation into an activist, which appears to coincide with her coming of age. Malala becomes an icon of the fight for gender equality and girls' education: "Education is education. [...] Education is neither Eastern nor Western, it is human" (136). If education is understood in this manner, as a basic human right, then everybody can relate to her fight. Then again, education is repeated three times in a very short extract, which marks her unmistakable narrative style.

Finally, Malala resorts to visual aids to enhance empathy and draw the reader into her experience. Numerous photographs include Malala as a child, from the time she was a baby until she started giving speeches at school (52i-viii). A further set of photographs focuses on the shooting, depicting events that happened shortly before and afterwards (212i-viii). Visual identification is a vehicle of empathy as it heightens connections and supports referentiality. Malala Yousafzai's strategy is similar to Zlata Filipović's in highlighting the image of an innocent child as a means to generating humanitarian affects. As Sidonie Smith notes when discussing Zlata's Diary and its use of photographs, "The innocence effect is [...] reinforced through the packaging of Zlata's Diary and the paratextual use of photographs that visualize the young girl's story as a sentimentalized drama of lost childhood" (2006: 144). Apart from providing a sympathetic reading, the photographs transform the reader into a witness. Among the various photographs we find some of the notes that she, with trembling hand, wrote when recovering from her head wound in hospital: "When will my father come? We dont [sic] have alot [sic] of money- Now my hair is small [sic]. [...] Hwo [sic] did this to me? Stop fights [sic] What happend [sic] to me?" (236-37). The quivering handwriting, emphasized by the spelling mistakes, shakes the reader's consciousness. It is as if one could actually see the shaky hand that wrote those things. The narrating "I" calls for a compassionate "humanitarian reading" (Slaughter 2009), involving the reader, who feels the ethical responsibility to denounce the situation that allows children to be targeted just because they want an education.

Having noted Malala's empathetic mechanisms in her autobiography, I would now like to turn my attention to some of her public appearances in the year that followed its release. On her seventeenth birthday, she visited Nigeria to ask for the release of abducted girls by Boko Haram and their rights to receive an education (Simpson 2014). Then, after receiving the news that she had been awarded the Nobel Peace Prize, she attended the Forbes Under 30 Summit. In an interview 
with Ronan Farrow, she used her signature humorous anecdotes to connect with her audience, as for example her teacher's reactions to her award: "They treat me like a normal student [...]. My teacher asked me 'where is your homework?' and I said 'Miss, I won the prize and I was quite busy'" (Forbes 2014). She did not need to finish her sentence to prompt enthusiastic applause and sympathetic laughter. She interspersed anecdotes for humor relief, but, turning to more serious matters, she persisted: "it's still my dream, to see every child, in Pakistan and all over the world, to [sic] get quality education" (Forbes 2014). A key moment of this interview is Malala's defense of Islam, as she stresses the common misconceptions against Islam as a religion that does not support women. Instead, she wishes the world to know that their reading of Islam is inaccurate: "in Islam it is not only your right to get education, but it is rather your responsibility [...] and this is both for boys and girls, men and women. So that needs to be clarified - that Islam uses a message of learning" (Forbes 2014). As noticed before, Malala resorts to parallelisms to create simple structures that allow her to emphasize her ideas in a repetitive manner. In order to combat the misuse of Islam by terrorists as well as issues such as child labor, the most important thing, she says, is "raising awareness" (Forbes 2014). Activism and testimonial acts, precisely those that have to do with human rights, entail just that awareness-raising (Schaffer and Smith 2004: 150). Regarding what Western audiences know of Islam to date, she says that it is a religion of "tolerance" (Forbes 2014), which strikes at the heart of the problem - the growing fears that this religion could be behind human rights abuses and terrorism. The answer, for Westerners and Islamic sects alike, she says, lies in "learning the real meaning of Islam" (Forbes 2014). In an interesting comment on her combined vision of feminism and Islam, she recalls the argument from her book (Yousafzai and Lamb 2013: 95) that the Prophet's wife was a "businesswoman" (Forbes 2014), which proves that women are allowed to work outside the home. Most remarkably, Malala points out that she is authentic when she speaks up for the rights of girls and children: "the role I have [...] is not something that has been given to me by someone; it is what I have decided [...] what I have chosen for myself" (Forbes 2014). Her insistence that her activist role was not imposed on her but was a matter of her choice bears an interpretation through the lens of what Smith and Watson call "metrics of authenticity" (2012). Further, Malala reminds her audience that compassion, moving you to help others, in turn makes one feel better (Forbes 2014). Interestingly, the idea that acts of compassion may trigger well-being traces back to Batson's empathy-altruism theory (1991), which would grant an appropriate response to her texts. Yet, the key to understanding the insertion of this remark here is perhaps, as Whitlock points out, that "compassionate concern for strangers and the desire to act on their behalf by a concerned third party is fundamental to modern western understandings of human rights activism" (2015: 39-40). 
On 10 December 2014, Malala Yousafzai became the youngest recipient of the Nobel Peace Prize. In her acceptance speech before the Nobel Committee in Oslo, she stressed the importance of acts over words. Thinking about children that are kept out of school, she said: "it is not time to pity them; it is time to take action" (Malala Fund 2014). On strategic empathizing grounds (Keen 2016), she resorts to the rhetoric of discursive parallel opposition: "it is not time to [...] it is time to [...]" (Malala Fund 2014). Therefore, even though she has referred to compassion as a basic human need, it is in fact necessary to move beyond. Rather, what we need is an empathic approach, one that overcomes pity "to bring about fundamental social change" (Krznaric 2014: ix). Malala chooses to address the terrorists, blaming them for misusing Islam: "Have you not learnt that in the Holy Koran Allah says "If you kill one person, it is as if you kill the whole humanity?" (Malala Fund 2014). This rhetorical question, which seeks really no answer, comes actually after several similar sentences, all of them starting the same way: "Have you not learnt [...]?” (Malala Fund 2014). Finally, she resorts to standing up for her community, something that she has in common with the tradition of testimony in which her life narrative is inscribed: "I tell my story not because it is unique, but because it is not; it is the story of many girls" (Malala Fund 2014). As we have seen, Malala's eloquent style resorts to frequent repetition for emphasis. In this speech, though Malala is already close to adulthood, she identifies herself as "one child" and claims that children do not understand the so-called war on terror. Thus, she asks: "Why is it that countries that we call strong are so powerful in creating wars but are so weak in bringing peace? Why is it? Why is it that giving guns is so easy but giving books is so hard? Why is it? Why is it that making tanks is so easy but building schools is so hard?" (Malala Fund 2014; emphasis added). Rhetorical repetition adds tension to her speech. The main issue - Why is it? - bears no response, thus challenging readers ethically. Resorting to the use of rhetorical questions emotionally loaded and with nuanced repetition is not new; Zlata's Diary, commented in depth by Sidonie Smith (2006), is highly reliant on this narrative technique, which is not just how children talk, but one of the rhetorical strategies activists of all ages and backgrounds deploy to great effect in their consciousness-raising discourses. For instance, the strategy is clearly visible in one of the multiple entries where Zlata emotionally calls for the end of the war: "Will this war ever stop? Will our suffering stop [...]?" (Filipović 1995: 106; emphasis added). As such, emphatic repetition may be read as one of the empathetic mechanisms suggested in the introduction. These questions "ignite an affective charge" and "serve as a means of shaming" readers (Smith 2006: 148), since the answer to those rhetorical questions is far from simple. Indeed, it seems as if that escapes our control and is in the hands of those in power, but Malala reminds us that "we must work, not wait; not just the politicians and world leaders, we 
all need to contribute - me, you, we; it is our duty" (Malala Fund 2014). Malala's call to action cannot possibly be more straightforward than that. Her choice of pronouns involves readers in her fight: "we [...] we all [...] me, you, we" (Malala Fund 2014). The fluctuating rhythmic progress of the narrative, shifting from the first-person singular to the first-person plural is strategically devised to involve readers who are called to redress the situation and compelled to do so in moral terms ("it is our duty"). Enjoining the discourse of humanitarianism with moral ethics is a trademark of rights narratives. ${ }^{5}$ Whitlock notes in Soft Weapons how rights narratives can elicit an "ethical response" provided "empathic witnessing" takes place (2007: 77). Importantly, the collective pronoun combines the force of testimonial accounts of oppressed others with the "ethical witness" position of readers as part of the fight (77). We are at once distant spectators and operative members of the same community of human beings.

When Malala turned eighteen she inaugurated the first school for Syrian girl refugees that her foundation has funded in Lebanon (Clayton 2015): "Today on my first day as an adult, on behalf of the world's children, I demand of leaders we must invest in books instead of bullets" (Westall 2015). This shows that Malala remains true to her original discourse favoring education as the most potent weapon (Yousafzai and Lamb 2013: 131). When interviewed by the BBC after the opening ceremony, she said that the place that she is speaking from helps her message: "It makes my voice more powerful, because it's not just my voice but the voice of all these children" (BBC News 2015). Her ability to speak for those who are not usually heard is part of the reason why she has become an icon worldwide. In the tradition of other activists, she bears witness to the conditions that rob others of their voices. The individual "I" is made to stand for a community of others, narrating the story of a complex plural self, typical of testimonial accounts, which Smith and Watson call collective "I-formations" (2012). By testifying, her life narrative becomes that of a community - girls that are excluded from education. Asked about her turning eighteen, Malala emphasizes the fact that her age has not changed her: "Being an adult does not stop me from continuing my campaign for children's issues" (BBC News 2015). She purposefully defends her unchanged attitude - "I don't think much has changed, but I do feel responsibilities which I always have felt" - and stresses that "the worst thing is that world leaders are not paying attention" (BBC News 2015). That has been her discourse for years now, since her speech at the UN when she turned sixteen, a discourse that, following Malala's story and its impact, succeeds in effecting empathy as a vehicle for change.

\footnotetext{
5 Judith Butler sees discussions of ethics as intrinsic to any life narrative, not just those related to human rights: "The 'I' does not stand apart from the prevailing matrix of ethical norms and conflicting moral frameworks" (2007: 7).
} 


\section{CONCLUSION}

The delicate balance between witnessing and involvement lies in the construction of an emotional bond. Empathy hangs in an almost equally delicate balance, between closeness and distance, appealing as much to our similarities as to our differences. The "affective appeal" Smith and Watson (2017) discuss at length relies on stereotypes of vulnerability and innocence, by emphasizing what is common to human experience, such as childhood and coming of age, while at other times stressing major ethnic differences between the victimized subject and the reader. Emerging out of that productive tension, the self-presentation human rights life narratives manage to convey depends on how successful that appeal is. Malala's life narrative, like many other examples of human rights life narratives, succeeds in creating such an affective bond. By deploying strategic empathy, these narratives make readers want to act in consequence, thus advancing the possibility of pro-social behavior. The carefully placed propaganda of the Malala Fund at the end of the book is designed to compel an engaged reader to contribute to her cause, highlighting their community projects for girls' education in Pakistan, Nigeria, Kenya, Sierra Leone, Jordan and Lebanon. Malala's school for Syrian girl refugees in the latter country, for example, was the first of its kind (Westall 2015). Such humanitarian discourse is patent on the Malala Fund website, asking for donors' aid straightforwardly. Combining the appeal of the local and the global, stressing similarities as well as differences among peoples and their ideas on the right to education, the stories featured on the platform converge on the figure of the child as symbolic of hope and future in an attempt to draw the international community to redress injustice.

Despite the need for critical distance, much may be gained from an empathic and respectful approach to life narrative. It may be worthwhile to consider the world anew, from another's viewpoint (Nussbaum 2012: 36), in an effort to understand the experiences the narrating "I" describes. Empathy may perhaps serve a further role in relation to life narratives dealing with human rights, one that can be "potentially transformative" (Schaffer and Smith 2004: 8):

\footnotetext{
Within the context of life narrating, claims take on a human dimension, calling for the listener/reader to become more self-reflexive, more informed, more active. Acts of listening and reading, however diverse in location and purpose, seed new awareness, recognition, respect, and willingness to understand, acknowledge, and seek redress for rights violations. While such narrative acts and readings are not a sufficient ground for social change, they are a necessary ground. (226)
}

Appealing to our sense of responsibility, human rights life narratives can "spur social change" (229). Thus, the discourse of victimization is turned into a narrative of hope: "at this historical moment human rights activism, and the discourse sustaining 
it, remains the most viable hope for extending democracy, social justice, and freedom" (234). Malala demonstrates how the multiple stories that construct her life narrative, "taken together, mount a powerful argument for the efficacy of storytelling in advancing the ongoing and constantly transforming pursuit of social justice, emanating from, but not limited to, the human rights project inaugurated with the UDHR" (233).

Despite the fact that human rights life narratives remain "highly problematic" (31), the understandable qualms against naiveté and a positivistic reading of life narrative need to be overcome if human rights claims are to be assessed and redressed. Richard Ashby Wilson and Richard D. Brown note how, in this globalized circuit of testimony, 'individual victims' narratives seem to be a necessary component in the mobilization of empathy" (2009: 20). Although some criticism may emerge against Malala because of the role of the media in making her a public figure (Ahmed 2014; Aheram 2014; Hines 2014; Rao 2015), her story has moved millions of people. ${ }^{6}$ Indeed, "stories mobilize social movements" (Frank 2010: 3). More specifically, human rights life narratives "can affect readers and prompt acts of engagement" (Schaffer and Smith 2004: 226). The key for readers and audiences to react might well be empathy: "Stories and social movements have a natural affinity because stories move people, in the sense of generating emotions and in creating agitation that shifts people's position" (Frank 2010: 133). Malala's story is moving, mainly because it is true; but it is also moving people to act - as she famously says in her interviews and on her website: "There's a moment when you have to decide whether to be silent or stand up" (Malala Fund 2014). In the context of globalization, life narratives such as Malala's that propose global peace and understanding and are aimed at fostering human rights may be both necessary and urgent.

\section{REFERENCES}

Aheram, J. 2014. "Malala: Puppet for US Imperialism". <http://www.original.antiwar. com/jayel_aheram/2014/05/16/malala-puppet-for-us-imperialism/>. (Accessed 10 Oct. 2015)

Ahmed, B. 2014. "What People in Pakistan Really Think about Nobel Prize Winner Malala Yousafzai". <http://www.thinkprogress.org/world/2014/10/10/3578820/ malala-yousafzai-nobel-prize/>. (Accessed 10 Oct. 2015)

Alcoff, L. M. and L. Gray-Rosendale. 1996. "Survivor Discourse". Getting a Life: Everyday Uses of Autobiography. Eds. S. Smith and J. Watson. Minneapolis: University of Minnesota Press. 198-225.

\footnotetext{
6 As Butler noted in the Afterword to PMLA special issue "The Humanities in Human Rights: Critique, Language, Politics", "there can be no rights without media" (2006: 1660).
} 
Batson, D. C. 1991. The Altruism Question: Toward a Social-Psychological Answer. New York: Erlbaum.

BBC News. 2015. "Malala: 'I promised to help people"'. YouTube, 13 Jul. <http:// www.youtube.com/watch?v=waWZnRvCRpE>. (Accessed 30 Aug. 2015)

Boltanski, L. 1991. Distant Suffering: Morality, Media, and Politics. Cambridge: Cambridge University Press. Trans. Graham Burchell.

Booth, W. C. 1988. The Company We Keep: An Ethics of Fiction. Berkeley: University of California Press.

Butler, J. 2006. "Afterword”. PMLA 121 (5): 1658-1661.

Butler, J. 2007. Giving an Account of Oneself. New York: Fordham University Press.

Chouliaraki, L. 2006. The Spectatorship of Suffering. London: Sage.

Clayton, J., ed. 2015. "Malala marks 18th birthday by opening school for girl refugees". UNHCR, 13 Jul. <http://www.unhcr.org/55a3dc935.html>. (Accessed 27 Aug. 2015)

CNN. 2013. "The Story of Malala Yousafzai". YouTube, interview by Fionnuala Sweeney, 12 Jul. <http://www.youtube.com/watch?v=NIqOhxQ0-H8>. (Accessed 18 Sept. 2015)

"Diary of a Pakistani Schoolgirl". 2009. BBC, 19 Jan. <http://www.news.bbc. co.uk/2/hi/south_asia/7834402.stm>. (Accessed 16 Sept. 2015)

Douglas, K. 2009. Contesting Childhood: Autobiography, Trauma, and Memory. New Brunswick: Rutgers University Press.

Douglas, K. 2015. "Ethical Dialogues: Youth, Memoir, and Trauma". a/b: Auto/ Biography Studies 30 (2): 271-288.

Douglas, K. 2017. "Malala Yousafzai, Life Narrative and the Collaborative Archive". Life Writing 14 (3): 297-311.

Douglas, K. and A. Poletti. 2016. Life Narratives and Youth Culture: Representation, Agency and Participation. London: Palgrave Macmillan.

Eisenberg, N., ed. 1982. The Development of Prosocial Behavior. New York: Academic Press.

Ellick, A. B. 2009. "A Schoolgirl's Odyssey". YouTube, New York Times, 13 Oct. <http://www.youtube.com/watch?v=a6T5DeZ9Z4c >. (Accessed 30 Aug. 2015)

Ellick, A. B. and I. Ashraf. 2009. "Class Dismissed: The Death of Female Education". New York Times, Times Documentaries. <http://www.nytimes. com/video/world/asia/100000001835296/class-dismissed.html>. (Accessed 30 Aug. 2015) 
Filipović, Z. 1995. Zlata's Diary: A Child's Life in Sarajevo. London: Penguin. Trans. Christina Pribichevich-Zoric.

Frank, A. W. 2010. Letting Stories Breathe: A Socio-Narratology. Chicago: Chicago University Press.

Forbes. 2014. "Malala on Peace, Drones and Islam". YouTube, interview by Ronan Farrow, 22 Oct. <http://www.youtube.com/watch?v=iAhjiUh-Pho>. (Accessed 30 Aug. 2015)

Gullestad, M. 1996. Everyday Life Philosophers: Modernity, Morality and Autobiography in Norway. Oslo: Scandinavian University Press.

Hammond, M. M. and S. J. Kim. 2014. Rethinking Empathy through Literature. New York: Routledge.

Harvard Foundation. 2013. "Malala Yousafzai Speaks at Harvard". YouTube, 17 Oct. <http://www.youtube.com/watch?v=e1tOe4SKbLU>. (Accessed 30 Aug. 2015)

Hesford, W. S. 2011. Spectacular Rhetorics: Human Rights Visions, Recognition, Feminisms. Durham: Duke University Press.

Hines, N. 2014. "Is Malala A Puppet of the West?" The Daily Beast, 4 Dec. <http:// www.thedailybeast.com/articles/2014/04/12/has-malala-become-a-puppet-ofthe-west.html>. (Accessed 10 Oct. 2015)

ITV. 2013. "Malala meets the Queen at Buckingham Palace". ITV News, 18 Oct. $\quad<$ http://www.itv.com/news/2013-10-18/malala-meets-the-queen-atbuckingham-palace/>. (Accessed 22 May 2017)

Jensen, M. and M. Jolly, eds. 2014. We Shall Bear Witness: Life Narratives and Human Rights. Madison: University of Wisconsin Press.

Jolly, M. 2014. "Introduction: Life / Rights Narratives in Action". We Shall Bear Witness: Life Narratives and Human Rights. Eds. M. Jensen and M. Jolly. Madison: University of Wisconsin Press. 3-22.

Keen, S. 2016. "Life Writing and the Empathetic Circle". Concentric: Literary and Cultural Studies 42 (2): 9-26.

Krznaric, R. 2014. Empatby: A Handbook for Revolution. London: Rider.

LaCapra, D. 2001. Writing History, Writing Trauma. Baltimore: Johns Hopkins University Press.

Malala Fund. 2014. "Malala Yousafzai Nobel Peace Prize Speech". YouTube, 11 Dec. <http://www.youtube.com/watch?v=MOqIotJrFVM>. (Accessed 30 Aug. 2015)

Martínez García, A. B. 2016. "Narrative Emotions and Human Rights Life Writing". On the Move: Glancing Backwards to Build a Future in English Studies. Eds. 
A. Ibarrola-Armendariz and J. Ortiz de Urbina Arruabarrena. Bilbao: University of Deusto. 127-132.

Martínez García, A. B. Forthcoming. "Construction and Collaboration in Life Writing Projects: Malala Yousafzai's Activist 'I'”. Journal of Writing in Creative Practice. Accepted 16 Jan. 2018.

Nussbaum, M. C. 2001. Upheavals of Thought: The Intelligence of Emotions. Cambridge: Cambridge University Press.

Nussbaum, M. C. 2012 (2010). Not for Profit: Why Democracy Needs the Humanities. Princeton: Princeton University Press.

Rao, M. 2015. "Why Do Some Pakistanis Hate Malala So Much?" Huffington Post, 9 Oct. <http://www.huffingtonpost.com/entry/why-do-pakistanis-hate-malala_ 56174cede4b0e66ad4c74739>. (Accessed 10 Oct. 2015)

Rorty, R. 1993. "Human Rights, Rationality, and Sentimentality". On Human Rights: The Oxford Amnesty Lectures, 1993. Ed. S. Shute and S. L. Hurley. New York: Basic. 111-134.

Schaffer, K. and S. Smith. 2004. Human Rights and Narrated Lives: The Ethics of Recognition. New York: Palgrave Macmillan.

Schwarz, D. R. 2001. "A Humanistic Ethics of Reading". Mapping the Ethical Turn: A Reader in Ethics, Culture, and Literary Theory. Eds. T. F. Davis and K. Womack. Charlottesville: University Press of Virginia. 3-15.

Shuman, A. 2005. Other People's Stories: Entitlement Claims and the Critique of Empathy. Urbana: University of Illinois Press.

Simpson, J. 2014. "Malala's Appeal for Nigerian Kidnapped Girls' Release”. BBC, 14 Jul. <http://www.bbc.com/news/world-africa-28288819>. (Accessed 18 Sept. 2015)

Slaughter, J. R. 2009. "Humanitarian Reading". Humanitarianism and Suffering: The Mobilization of Empathy. Eds. R. A. Wilson and R. D. Brown. New York: Cambridge University Press. 88-107.

Smith, S. 2006. "Narratives and Rights: Zlata's Diary and the Circulation of Stories of Suffering Ethnicity”. WSQ: Women's Studies Quarterly 34 (1-2): 133-152.

Smith, S. and J. Watson. 2010 (2001). Reading Autobiography: A Guide for Interpreting Life Narratives. Minneapolis: Minnesota University Press.

Smith, S. and J. Watson. 2012. "Witness or False Witness?: Metrics of Authenticity, Collective I-Formations, and the Ethic of Verification in First-Person Testimony". Biography 35 (4): 590-626.

Smith, S. and J. Watson. 2017. Life Writing in the Long Run: A Smith \& Watson Autobiography Studies Reader. Ann Arbor: Michigan Publishing. 
Taylor, C. 1989. Sources of the Self: The Making of the Modern Identity. Cambridge: Cambridge University Press.

Westall, S. 2015. "Nobel winner Malala opens school for Syrian refugees". Reuters, 13 Jul. <http://www.reuters.com/article/2015/07/13/lebanon-malalaidUSKCNOPMOL320150713>. (Accessed 27 Aug. 2015)

Whitlock, G. 2007. Soft Weapons: Autobiography in Transit. Chicago: Chicago University Press.

Whitlock, G. 2015. Postcolonial Life Narratives: Testimonial Transactions. Oxford: Oxford University Press.

Wilson, R. A. and R. D. Brown, eds. 2009. Humanitarianism and Suffering: The Mobilization of Empathy. New York: Cambridge University Press.

Yousafzai, M. 2013. "Malala Yousafzai addresses United Nations Youth Assembly". YouTube, 13 Jul. <http://www.youtube.com/watch?v=3rNhZu3ttIU>. (Accessed 16 Feb. 2015).

Yousafzai, M. and C. Lamb. 2013. I Am Malala: The Girl Who Stood Up for Education and Was Shot by the Taliban. London: Weidenfeld \& Nicolson. 